\title{
CHEMICAL COMPOSITION OF BRAZILIAN SUNFLOWER VARIETIES
}

Rosa, P.M. ${ }^{1}$, Antoniassi, R. ${ }^{{ }^{*}}$, Freitas, S.C. ${ }^{2}$, Bizzo, H.R. ${ }^{2}$, Zanotto, D.L. $^{3}$, Oliveira, M.F. ${ }^{4}$, Castiglioni, V.B.R. ${ }^{4}$

${ }^{1}$ UFRRJ University, Seropedica, RJ, Brazil

2 Embrapa Food Technology, Av Americas 29501, Rio de Janeiro, RJ, Brazil, CEP 23020-470

${ }^{3}$ Embrapa Swine and Poultry, Concordia, SC, Brazil

${ }^{4}$ Embrapa Soybean, Londrina, PR, Brazil

Received: February 07, 2009

Accepted: June 02, 2009

\section{SUMMARY}

Sunflower is the world fourth most important source of edible oil, after palm oil, soybean and rapeseed/canola. Sunflower acreage in Brazil has been consolidated due to the constant efforts in genetic and agronomical studies carried out by Brazilian research institutions. Although easily adapted to many Brazilian regions, genetic and agronomical improvements were needed so that economically viable crops could be harvested. Sunflower varieties with interesting oil composition as well as noteworthy protein quality were obtained. As part of these efforts, two new varieties were developed by Embrapa Soybean, Embrapa 122 V2000 and Embrapa $F_{2}$ BRS 191. This work was aimed at evaluating the chemical composition of the seeds, defatted meal and oil quality of these varieties. The oil content varied from 44 to $52 \%$ in $\mathrm{F}_{2}$ BRS and from 36 to $47 \%$ in $\mathrm{E} 122$. Linoleic $(62-69 \%)$ and oleic $(20-25 \%)$ were the major fatty acids in both varieties. The protein content of the defatted meal ranged from 28 to $32 \%$. Slight differences were observed in amino acids profile, sterols and chlorogenic acid content.

Key words: seed, oil, sunflower, chemical composition, fatty acids, sterols

\section{INTRODUCTION}

The world production of sunflower seeds increased from 26 to 31 million metric tons between 2004 and 2006 (FAO, 2007), whereas the world production of sunflower oil was 10 million metric tons from 2005 to 2007, being overtaken only by palm, soybean and canola (USDA, 2007).

The Brazilian production of sunflower seed represents only $0.003 \%$ of the world production. The area occupied by sunflower crops is 87.8 thousands hectares, the productivity is $1463 \mathrm{~kg} / \mathrm{ha}$ and the production is 128.5 thousand tons (Brazilian Crop Assessment, 2008). 
There is an increasing utilization of sunflower in Brazil, due to its use as raw material for silage, oil production and its potential as a new source of energy from the renewable fuel production (Porto et al., 2008).

The versatile use of sunflower seeds resulted in a gradual growth of the sunflower acreage in Brazil. The world demand for sunflower oil has been increasing on average for $1.8 \%$ per year, but in 2002 the Brazilian growth was $5 \%$. The internal demand for sunflower oil increases on an average for $13 \%$ per year. In order to supply this demand, Brazil imports oil mainly from Argentina. In 2004, Brazil imported 11,756 tons of sunflower (seeds, meal and oil) lower than in 2003, when 26,607 tons were imported. This data indicates a considerable increase in self-sufficiency of edible oil. The annual consumption of sunflower oil in Brazil is estimated between 35 and 45 tons (Sunflower, Embrapa web-link, 2008).

The expansion of sunflower crop as the second summer crop in Brazil depends on constant evaluation of new cultivars obtained through identification of superior materials capable of expressing high yield and acceptable quality in different regions (Porto et al., 2008).

Sunflower crop has a great capacity for adaptation to varied latitudes, longitudes and photoperiods. In recent years, new agricultural practices such as crop rotation have been adopted in regions of grain production. Sunflower crop has interesting characteristics that meet farm requirements; it has higher drought resistance than maize and sorghum, high disease and insect resistance and it also improves soil conditions for following crops (Sunflower, Embrapa web-link, 2008).

Sunflower meal is a byproduct of industrial oil extraction of whole or dehulled seed (Stringhini et al., 2000). It can be used as an ingredient in feed production since it has high protein content. However, it also has a high insoluble fiber content which reduces digestible energy and a low lysine content (Silva et al., 2002).

The objective of this work was to evaluate the chemical composition of sunflower seed, meal and oil of the varieties Embrapa E122 and $F_{2}$ BRS developed by Embrapa.

\section{MATERIALS AND METHODS}

Sunflower varieties EMBRAPA122 V2000 (E122) and $\mathrm{F}_{2}$ BRS 191 ( $\mathrm{F}_{2}$ BRS) from Embrapa Soybean, Londrina, PR, Brazil, were analyzed.

Whole sunflower seeds were oven dried at $100^{\circ} \mathrm{C}$ for $60 \mathrm{~min}$ according to Bernardini (1983). Dehulling was performed in an industrial roller mill Tecmolin (São Paulo, Brazil) and the hulls were separated in an oscillatory sieve shaker Rotap RX29 (Tyler Industrial Products, OH, USA).

Moisture and ash analyses of sunflower seeds (whole and dehulled) and defatted meal were conducted according to AOCS Official Methods Ca 2c-25 and Ca 1155 (AOCS, 2004), respectively. Nitrogen content was determined according to AOAC 
33.2.11 (AOAC, 2005) and the conversion factor used to calculate protein content was 5.3, according to AOCS (2004). Crude fiber, neutral detergent fiber and acid detergent fiber were conducted according to the official methods AOAC, 4.06.02, 4.06.04 and 4.06.03, respectively (AOAC, 2005). Amino acid content in defatted sunflower meal was determined according to the official method 4.1.11 (AOAC, 2005).

\section{Determination of chlorogenic acid and caffeic acid in defatted meal}

Extraction of phenolic compounds was carried out with $70 \%$ aqueous methanol solution, by shaking for 120 minutes, at room temperature. After filtration into a volumetric flask, the volume was adjusted for $100 \mathrm{ml}$ with the same solution. Analysis was performed by HPLC using a C18 column $(25 \mathrm{~cm} \times 4 \mathrm{~mm} \times 5 \mu \mathrm{m})$, and an isocratic mobile phase of $35 \%$ methanol $65 \%$ aqueous acetic acid (1\%), and flux of $0.5 \mathrm{ml} / \mathrm{min}$. For quantification purposes, standard solutions of caffeic acid and chlorogenic acid were injected and values of maximum absorbance measured at $313 \mathrm{~nm}$ using a diode array detector. Identification was based on a comparison of retention times from standards and samples and by UV spectra recording.

\section{Oil}

Sunflower seeds (whole and dehulled) were ground and oil was extracted with petroleum ether $\left(30-60^{\circ} \mathrm{C}\right)$ in a Soxhlet apparatus for $16 \mathrm{~h}$. Acidity, unsaponifiable matter, iodine value and saponification value were measured according to AOCS official methods (AOCS, 2004). Refraction index was performed in an Abbe refractometer at $40^{\circ} \mathrm{C}$ and Lovibond color was measured at Lovibond Tintometer HF Scientifics PFX 990.

\section{Fatty acid composition}

Methyl esters of fatty acids were prepared according to Hartman \& Lago (1973). Gas chromatography was performed in a HP 5890 series II chromatograph fitted with a cianopropylsiloxane capillary column $(60 \mathrm{~m} \times 0.32 \mathrm{~mm} \times 0.25 \mu \mathrm{m})$, and oven temperature from 150 to $200^{\circ} \mathrm{C}$ at $1.3^{\circ} \mathrm{C} / \mathrm{min}$. The carrier gas used was hydrogen, at $2.5 \mathrm{ml} / \mathrm{min}$ (measured at $40^{\circ} \mathrm{C}$ ). Injection of $1.0 \mu \mathrm{l}$ of a $2 \%$ dichloromethane solution of the sample was done in an injector operating at $250^{\circ} \mathrm{C}$ and split mode ( $1: 50$ ) and FID detector was kept at $280^{\circ} \mathrm{C}$. Results were expressed as weight percent (area normalization). Identification of FAME was based on comparison of retention times with those of NU CHEK standards 62, 79 and 87 (Elysian, MN).

\section{Sterols composition}

After extraction of unsaponifiable matter (AOCS method Ca 6b-53), sterols were obtained by preparative thin layer chromatography in Merck silica 60G plates, eluted with petroleum ether-diethyl ether (70:30). Gas chromatography was performed in a HP 5890 series II chromatograph fitted with a 100\% polydimethylsi- 
loxane capillary column $(25 \mathrm{~m} \times 0,32 \mathrm{~mm} \times 0.17 \mu \mathrm{m})$ with an oven temperature program of 250 to $290^{\circ} \mathrm{C}\left(3^{\circ} \mathrm{C} / \mathrm{min}\right)$ and hydrogen as carrier gas $(2.5 \mathrm{ml} / \mathrm{min}$, measured at $40^{\circ} \mathrm{C}$ ). Injector was kept at $300^{\circ} \mathrm{C}$ in split mode $(1: 50)$ while $1.0 \mu \mathrm{l}$ of a $2 \%$ dichloromethane sample was injected. Flame ionization detector (FID) was operated at $300^{\circ} \mathrm{C}$.

Identification of sterols was made in an Agilent 6890GC coupled to a $5973 \mathrm{~N}$ mass selective detector equipped with a fused silica HP5 $(25 \mathrm{~m} \times 0.25 \mathrm{~mm} \times 0.25$ $\mu \mathrm{m}$ ). EI-mass spectra were recorded at $70 \mathrm{eV}$. Injector (split mode 100:1) was operated at $300^{\circ} \mathrm{C}$. Helium was used as carrier gas $(1.0 \mathrm{ml} / \mathrm{min})$. Other conditions as above.

All analyses were performed in duplicate.

\section{RESULTS AND DISCUSSION}

Chemical compositions of dehulled and whole seeds and meals are presented in Tables 1 and 2.

Table 1: Chemical composition (g $100 \mathrm{~g}^{-1}$ ) of sunflower varieties

\begin{tabular}{lcccc}
\hline & \multicolumn{2}{c}{ E122 } & \multicolumn{2}{c}{$\mathrm{F}_{2}$ BRS } \\
\cline { 2 - 5 } & Seed & Dehulled seed & Seed & Dehulled seed \\
\hline Moisture & 6.74 & 2.48 & 5.65 & 3.07 \\
Protein (nitrogen $\times 5.3$ ) & 18.23 & 19.66 & 14.73 & 17.65 \\
Ash & 3.88 & 4.33 & 2.97 & 3.23 \\
Oil & 36.14 & 46.81 & 44.08 & 51.91 \\
Crude fiber & 11.35 & 10.28 & 10.68 & $\mathrm{np}$ \\
\hline
\end{tabular}

np-not performed

Table 2: Chemical composition (g $100 \mathrm{~g}^{-1}$ ) of defatted sunflower meal of the varieties Embrapa $\mathrm{E} 122$ and $\mathrm{F}_{2}$ BRS

\begin{tabular}{lcccc}
\hline & \multicolumn{2}{c}{ E122 } & \multicolumn{2}{c}{$\mathrm{F}_{2}$ BRS } \\
\cline { 2 - 5 } & Meal & Dehulled meal & Meal & Dehulled meal \\
\hline Moisture & 7.95 & 9.53 & 7.91 & 8.65 \\
Protein (nitrogen $\times 5.3$ ) & 28.41 & 36.20 & 31.48 & 32.12 \\
Ash & 6.33 & 7.40 & 5.32 & 6.01 \\
Oil & 2.85 & 2.02 & 5.81 & 2.96 \\
Crude fiber & 18.40 & $\mathrm{np}$ & 15.28 & $\mathrm{np}$ \\
Neutral detergent fiber & $\mathrm{np}$ & 19.52 & $\mathrm{np}$ & 27.62 \\
Acid detergent fiber & $\mathrm{np}$ & 15.35 & $\mathrm{np}$ & 18.41 \\
\hline
\end{tabular}

np-not performed

The variety $\mathrm{F}_{2}$ BRS had higher oil contents for whole (44\%) and dehulled (52\%) seeds than E122 (47 and 36\%, respectively).

Grompone (2005) found 55\% of oil in sunflower kernels and around $40 \%$ in seeds whereas Carvalho et al. (2006), studying different sunflower genotypes dur- 
ing the period 2004/2005, reported that their oil contents ranged from 29.5 to $50.2 \%$, depending on the region and agricultural conditions.

Crude protein content of whole and dehulled seeds varied from 15 to 20\%. Protein and oil contents of dehulled samples were higher than those of whole seeds because the fraction of hulls varied from 16 to $45 \%$ of the seed weight and it was mainly built of cellulose and lignin with low levels of oil and proteins (Grompone, 2005).

Crude fiber contents in dehulled samples of the variety E122 was 11.25 and $10.28 \%$, respectively, and a small reduction of fiber was probability due to an incomplete dehulling. The crude fiber content of $\mathrm{F}_{2}$ BRS was $10.68 \%$.

Hull contents in E122 and $F_{2}$ BRS were 41.4 and $40.5 \%$, respectively. Hartman et al. (1999) found that the hull content of Brazilian sunflower varieties ranged from 39.3 to $57.5 \%$. Pedrosa et al. (2000) reported the hull content in Spanish sunflower varieties varying from 20.26 to $23.75 \%$ and Singh et al. (1999) found the hull content in Indian sunflower varieties varying from 22 to $28 \%$.

In order to remove hulls from sunflower seeds, Bernardini (1983) suggested a pre-heating treatment followed by a roller mill stage, which caused an incomplete separation of hulls and a certain percentage of nut breakage. This treatment produced better yield when applied to the variety E122. It is important to provide pretreatment conditions suitable for each variety.

Moisture of samples was below 10\%, within the limit described by Grompone (2005) as necessary to avoid enzymatic reactions.

The crude protein content of defatted sunflower seeds varied from 28.4 to $36.2 \%$, while the fiber content ranged from 15 to $27 \%$, depending on the method.

The nutritional values of defatted sunflower seeds reported by Stringhini et al. (2000) for protein, detergent acid and neutral detergent fiber were 27.36, 31.68 and $42.15 \%$, respectively. These values seem to be related to dehulled seeds. Furlan et al. (2001) reported protein and crude fiber contents of 34.0 and $21.7 \%$, respectively. Singh et al. (1999) reported values of acid detergent fiber and lignin of defatted sunflower meal (with hull) varying from 27 to $32 \%$ and from 9 to $13.6 \%$, respectively.

The results of fiber content found in literature vary according to the processing method but also to differences in the analytical procedure, which also depends on the analytical conditions at hydrolysis. For example, acid detergent-sensitive fiber measures lignin and cellulose whereas detergent-neutral fiber measures also hemicelluloses content (Van Soest, 1967).

Crude fiber is obtained by a hydrolysis process of the soluble fiber fraction and variable quantities of the insoluble fiber. It is estimated that only $20 \%$ of hemicellulose, 10 to $40 \%$ of lignin and from 50 to $90 \%$ of cellulose are left after drastic treatment for crude fiber determination (Filisetti-Cozze and Laiolo, 1991). 
Concerning amino acid composition of defatted sunflower meals, the dehulled samples had higher contents than expected. Small variations are described in the literature by Canibe et al. (1999), Stringhini et al. (2000) and Sen and Bhattacharyya (2000).

Table 3: Amino acid profile (g $100 \mathrm{~g}^{-1}$ ) of defatted sunflower meal

\begin{tabular}{lcccc}
\hline \multirow{2}{*}{ Amino acid } & \multicolumn{3}{c}{ E122 } & \multicolumn{3}{c}{$\mathrm{F}_{2}$ BRS } \\
\cline { 2 - 5 } & Defatted meal & Dehulled defatted meal & Defatted meal & Dehulled defatted meal \\
\hline Lysine & 1.19 & 1.46 & 1.48 & 1.23 \\
Histidine & 0.65 & 0.88 & 0.81 & 0.64 \\
Ammonia & 0.22 & 0.32 & 0.32 & 0.31 \\
Arginine & 2.15 & 3.00 & 2.49 & 2.01 \\
Aspartic acid & 2.41 & 3.28 & 3.10 & 2.37 \\
Threonine & 0.96 & 1.20 & 1.14 & 1.02 \\
Serine & 1.14 & 1.46 & 1.34 & 1.16 \\
Glutamic acid & 5.7 & 7.72 & 6.47 & 5.34 \\
Proline & 1.11 & 1.65 & 1.37 & 0.73 \\
Glycine & 1.45 & 1.87 & 1.70 & 1.41 \\
Alanine & 1.13 & 1.52 & 1.41 & 1.13 \\
Cystine & 0.64 & 0.81 & 0.79 & 0.66 \\
Valine & 1.31 & 1.75 & 1.65 & 1.28 \\
Methionine & 0.59 & 0.78 & 0.77 & 0.69 \\
Isoleucine & 1.12 & 1.52 & 1.37 & 1.07 \\
Leucine & 1.65 & 2.19 & 2.03 & 1.66 \\
Tyrosine & 0.57 & 0.83 & 0.77 & 0.60 \\
Phenylalanine & 1.27 & 1.69 & 1.47 & 1.21 \\
Total & 25.04 & 33.93 & 30.58 & 24.52 \\
\hline
\end{tabular}

Lysine content is lower than in soybean meal, which is a limitation for feed use as well as fiber content (Stringhini et al., 2000). According to Silva et al. (2002) and Furlan et al. (2001), however, sunflower meal could be used as partial replacement of soybean meal.

The fatty acid composition was shown in Table 4 . The palmitic acid content (C16:0) varied from 5.47 to $5.90 \%$ and the total saturated fatty acids varied from 9.55 to $10.11 \%$, which is considered one of the lowest levels among the edible vegetable oils, close to canola oil which is found to be the lowest (Przybylski et al., 2005).

The oleic acid content (C18:1) of the variety E122 (whole and dehulled seeds) was 25.77 and $26.45 \%$, respectively, and for the variety $F_{2}$ BRS 20.70 and $20.99 \%$, respectively. The linoleic acid contents (C18:2) were 63.59, 62.33, 69.62 and 68.62 , respectively. The variety E122 had a higher oleic fatty acid and a lower linoleic acid than the variety $\mathrm{F}_{2} \mathrm{BRS}$. Both varieties may be classified as high-linoleic sunflower varieties (Figure 1). 
Table 4: Fatty acid composition (\%) of sunflower oil from the varieties Embrapa E122 and $\mathrm{F}_{2} \mathrm{BRS}$

\begin{tabular}{|c|c|c|c|c|c|}
\hline \multirow[b]{2}{*}{ Fatty acid } & \multicolumn{2}{|c|}{ E122 } & \multicolumn{2}{|c|}{$\mathrm{F}_{2} \mathrm{BRS}$} & \multirow{2}{*}{$\begin{array}{c}\text { Sunflower oil } \\
\text { (Codex Alimentarius, } \\
\text { 2001) }\end{array}$} \\
\hline & $\begin{array}{l}\text { Whole } \\
\text { seed }\end{array}$ & $\begin{array}{l}\text { Dehulled } \\
\text { seed }\end{array}$ & $\begin{array}{l}\text { Whole } \\
\text { seed }\end{array}$ & $\begin{array}{l}\text { Dehulled } \\
\text { seed }\end{array}$ & \\
\hline C14:0 & $\mathrm{nq}$ & $\mathrm{nq}$ & $\mathrm{nq}$ & $\mathrm{nq}$ & $<0.2$ \\
\hline C16:0 & 5.90 & 5.73 & 5.61 & 5.47 & $5.0-7.6$ \\
\hline C16:1 & $\mathrm{nq}$ & 0.02 & $\mathrm{Nq}$ & nq & $<0.3$ \\
\hline C18:0 & 3.53 & 3.47 & 3.25 & 3.26 & $2.7-6.5$ \\
\hline C18:1 & 25.77 & 26.45 & 20.70 & 20.99 & $14.0-39.4$ \\
\hline C18:2 trans & $\mathrm{nq}$ & 0.45 & nd & nd & - \\
\hline C18:2 & 63.59 & 62.33 & 69.62 & 68.62 & 48.3-74.0 \\
\hline C20:0 & 0.12 & 0.10 & 0.04 & 0.12 & $0.1-0.5$ \\
\hline C18:3 & $\mathrm{nq}$ & $\mathrm{nq}$ & 0.02 & $\mathrm{nq}$ & $<0.3$ \\
\hline C20:1 & $\mathrm{nq}$ & 0.02 & 0.03 & 0.33 & $<0.5$ \\
\hline C22:0 & 0.56 & 0.54 & 0.68 & 0.70 & $0.3-1.5$ \\
\hline C22:1 & $\mathrm{nq}$ & $\mathrm{nq}$ & $\mathrm{nq}$ & $\mathrm{nq}$ & $<0.3$ \\
\hline $\mathrm{C} 24: 0$ & $\mathrm{nq}$ & 0.07 & 0.05 & $\mathrm{nq}$ & $<0.5$ \\
\hline C24:1 & $\mathrm{nq}$ & $\mathrm{nq}$ & $\mathrm{nq}$ & $\mathrm{nq}$ & $<0.5$ \\
\hline Not identified & 0.52 & 0.70 & - & 0.50 & - \\
\hline Saturated fatty acids & 10.11 & 9.91 & 9.63 & 9.55 & - \\
\hline Monounsaturated fatty acids & 25.77 & 26.49 & 20.73 & 21.32 & - \\
\hline Polyunsaturated fatty acids & 63.59 & 62.78 & 69.64 & 68.62 & - \\
\hline
\end{tabular}

nq-not quantified; nd-not detected

Two facts regarding the composition of regular sunflower oil are worth noting from the nutritional viewpoint: it provides an essential fatty acid (linoleic acid) and a lower content of palmitic acid as compared with others oils. Palmitic acid is believed to increase LDL-C (low density lipoprotein), which is associated with cardiovascular disease risk (Grompone, 2005).

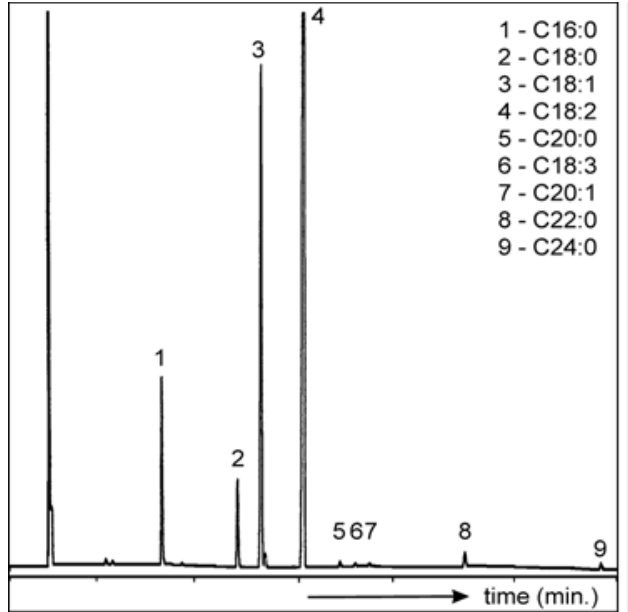

Figure 1: Gas chromatogram of fatty acids methyl esters from sunflower oil (the variety $F_{2}$ BRS)

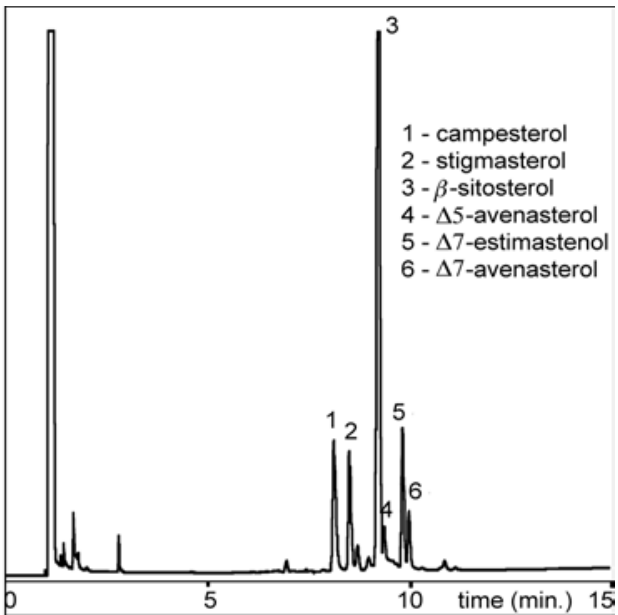

Figure 2: Gas chromatogram of free sterols from sunflower oil (the variety E122) 
Linoleic and linolenic acids (C18:3) are considered as essential fatty acids for humans, but the sunflower oil has a low content of the later. On the other hand, the presence of linolenic acid can reduce oxidative stability of oils. In this work, the linolenic content of the studied varieties was $0.02 \%$.

There was no difference between Embrapa E122 and $\mathrm{F}_{2}$ BRS concerning their physicochemical characteristics of oil. The iodine and saponification values, refractive index and unsaponifiable matter were within the limits prescribed in the Codex Alimentarius (2001).

The acid value of sunflower oil from $\mathrm{F}_{2}$ BRS was larger than that from E122, probably due to hydrolysis of triacilglycerol by lipases.

Table 5: Chemical and physical characteristics of sunflower oils from the two varieties

\begin{tabular}{|c|c|c|c|c|c|}
\hline \multirow[b]{2}{*}{ Parameter } & \multicolumn{2}{|c|}{ E122 } & \multicolumn{2}{|c|}{$\mathrm{F}_{2} \mathrm{BRS}$} & \multirow{2}{*}{$\begin{array}{c}\text { Sunflower Oil } \\
\text { (Codex Alimentarius, } \\
\text { 2001) }\end{array}$} \\
\hline & $\begin{array}{l}\text { Whole } \\
\text { seed }\end{array}$ & $\begin{array}{l}\text { Dehulled } \\
\text { seed }\end{array}$ & $\begin{array}{l}\text { Whole } \\
\text { seed }\end{array}$ & $\begin{array}{l}\text { Dehulled } \\
\text { seed }\end{array}$ & \\
\hline Unsaponifiable matter (\%) & 1.03 & 0.76 & 1.04 & 1.02 & $<1.5$ \\
\hline lodine value $\left(\mathrm{g} \mathrm{I}_{2} / 100 \mathrm{~g}\right)$ & 132.3 & 130.7 & 138.5 & 137.2 & $118-141$ \\
\hline Saponification value $(\mathrm{mg} \mathrm{KOH} / \mathrm{g})$ & 193.9 & 195.33 & 193.2 & 194.0 & $188-194$ \\
\hline Acid value $(\mathrm{mg} \mathrm{KOH} / \mathrm{g})$ & 0.80 & 0.82 & 4.10 & 4.09 & $<4$ \\
\hline Refraction index, $\left(\mathrm{n}_{\mathrm{D}} 40^{\circ} \mathrm{C}\right)$ & 1.4679 & 1.4617 & 1.4652 & 1.4672 & $1.461-1.468$ \\
\hline $\begin{array}{l}\text { Lovibond color: } \\
\text { R-red Y-yellow; (51/4"cell) }\end{array}$ & $\begin{array}{l}5.4 \mathrm{R} \\
-70.0 \mathrm{Y}\end{array}$ & $\begin{array}{l}7.3 \mathrm{R} \\
-70.0 \mathrm{Y}\end{array}$ & $\begin{array}{l}7.6 \mathrm{R} \\
-70.0 \mathrm{Y}\end{array}$ & $\begin{array}{l}8.5 \mathrm{R} \\
-70.0 \mathrm{Y}\end{array}$ & - \\
\hline
\end{tabular}

Sunflower oil was characterized by a relatively high percentage of $\Delta$-7-sterols ( $\Delta-7$ estimastenol and $\Delta-7$ avenasterol) (Figure 2 ).

The total ion chromatogram and the mass spectrum of 7 -stigmastenol are shown in Figure 3. The content of $\beta$-sitosterol was higher in $\mathrm{F}_{2}$ BRS than in E122 and stigmasterol and $\Delta$-7-sterols were higher in E122, but similar to the values prescribed by Codex Alimentarius (2001).

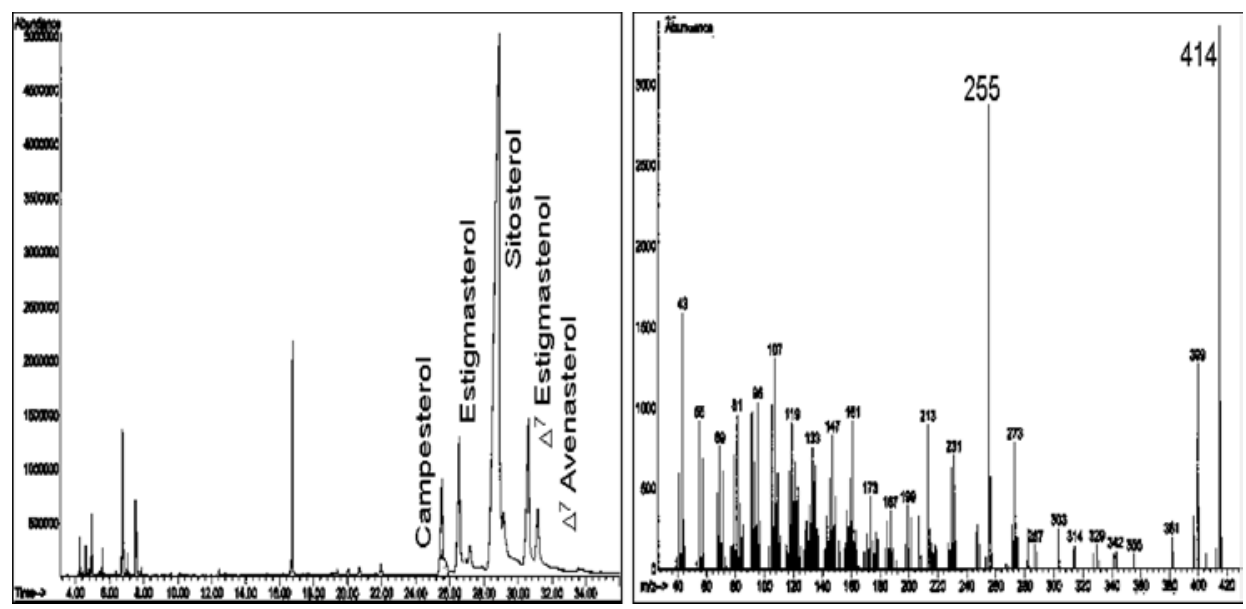

Figure 3: Total ion chromatogram of sterols and mass of delta 7-stigmastenol. 
In almost all vegetable fats and oils, sterols are quantitatively the most important unsaponifiable component. They are also characteristic of the genuineness of vegetable oils. Existing differences between sterol compositions make them unique and the most suitable markers for determining the botanical origins of oils and hence tracking commercial frauds (Aparicio and Aparicio-Ruiz, 2000).

Table 6: Leves of desmethylsterols (as a percentage of total sterols) in sunflower oils from the different varieties

\begin{tabular}{lccccc}
\hline \multirow{2}{*}{ Sterol } & \multicolumn{2}{c}{ E122 } & \multicolumn{2}{c}{$\mathrm{F}_{2}$ BRS } & $\begin{array}{c}\text { Sunflower oil } \\
\text { (Codex Alimentarius, } \\
\text { 2001) }\end{array}$ \\
\cline { 2 - 6 } & Whole seed & Dehulled seed & Whole seed & Dehulled seed & $6.5-13.0$ \\
\hline Campesterol & 9.80 & 9.82 & 9.47 & 9.53 & $6.0-13.0$ \\
Stigmasterol & 11.06 & 10.18 & 6.93 & 7.00 & $50-70$ \\
Beta sitosterol & 59.60 & 56.87 & 64.66 & 65.35 & $<6.9$ \\
$\Delta 5$ avenasterol & 1.84 & 2.78 & 2.83 & 3.12 & $6.5-24.0$ \\
$\Delta 7$ stimastenol & 10.19 & 10.46 & 8.55 & 7.90 & $3.0-7.5$ \\
$\Delta 7$ avenasterol & 4.22 & 4.54 & 4.00 & 3.52 & - \\
Unidentified & 3.28 & 5.36 & 3.54 & 3.56 & \\
\hline
\end{tabular}

The chlorogenic acid content of the sunflower defatted meal ranged from 1.00 to $1.38 \mathrm{~g} / 100 \mathrm{~g}$. Only traces of caffeic acid were detected.

Chlorogenic acid is an effective antioxidant but it binds to polar groups of the proteins and fiber, thereby strongly reducing the lysine content of meal. Presence of chlorogenic acid also causes color alteration that could impair the acceptability of the product (Sen and Bhattacharyya, 2000).

The chlorogenic acid content varied widely and results reported by Pedrosa et al. (2000) ranged from 0.063 to $0.097 \%$. According to Canibe et al. (1999), all phenolic compounds showed a high variation among 12 cultivars studied, ranging from 0.06 to $0.25 \%$ and Gonzalez-Perez et al. (2002) found a content of $2.5 \%$. Differences among chlorogenic acid contents were observed depending on the method used for the analytical determination by HPLC or spectrophotometric methods.

Table 1: Chlorogenic and caffeic acids contents in defatted sunflower meals (g 100g-1)

\begin{tabular}{lcc}
\hline Variety & Chlorogenic acid & Cafeic acid \\
\hline$E$ 122 whole seed & 1.00 & $\mathrm{nq}$ \\
$\mathrm{E} 122$ dehulled seed & 1.38 & $\mathrm{nq}$ \\
$\mathrm{F}_{2}$ BRS whole seed & 1.01 & $\mathrm{nq}$ \\
$\mathrm{F}_{2}$ BRS dehulled seed & 1.01 & $\mathrm{nq}$ \\
\hline
\end{tabular}

nq - detected, not quantified

\section{REFERENCES}

AOAC Official methods of analysis of the Association of Analytical Chemists. $18^{\text {th }}$ ed., Gaithersburg, Maryland: AOAC, Volume 1, 2005.

AOCS American Oil Chemists' Society. Official methods and recommended practices of the American Oil Chemists' Society. Champaign: AOCS, 2004. 
Aparicio, R., Aparicio-Ruiz, R., 2000. Authentication of vegetable oils by chromatographic techniques. Journal of Chromatography A 881(1-2): 93-104.

Bernardini, E., 1983. Raw Materials and Extraction Techniques, In: Oilseeds, Oils and Fats. (ed.) B.E. Oil Publishing House, Rome Volume I pp. 1-600.

Canibe, N., Martin-Pedrosa, M., Robredo, L.M., Bach-Knudsen, K.E., 1999. Chemical composition, digestibility and protein quality of 12 sunflower (Helianthus annuus L.) cultivars. Journal of the Science of Food and Agriculture 79(13): 1775-1782.

Codex Alimentarius. Fats, Oils and Related Products. $2^{\text {nd }}(e d$.$) , Roma, 2001. v. 8$.

Brazilian Crop Assessment: Grains-Crop 2008/2009-National Company of Food Supply. Available at <http://www.conab.gov.br/conabweb/download/safra/boletim_ingles_completo .pdf $>$ Accessed 25 nov 2008

FAO. Food and Agriculture Organization of the United Nations. Production ProdSTAT: Crops. [on-line]. Available at <http://faostat.fao.org/site/567/default.aspx> Accessed 15 mar. 2007.

Filisetti-Cozze, T.M.C.C., Laiolo, E.M., 1991. Insoluble, soluble, and total dietary fiber in brazilian foods. Revista Farmácia Bioquímica Universidade de São Paulo, 27(1): 83-99.

Furlan, A.C., Mantovani, C., Murakami, A.E., Moreira, I., Scapinello, C., Martins, E.N., 2001. Use of sunflower meal in broiler chicks feeding. Revista Bras. Zootec. 30(1): 158-164.

Gonzalez-Perez, S., Merck, K.B., Vereijken, J.M., Koningsveld, G.A., Gruppen, H., Voragen, A.G.J., 2002. Isolation and characterization of undenatured chlorogenic acid free sunflower (Helianthus annuus) proteins. Journal of Agricultural and Food Chemistry 50(6): 1713-1719.

Grompone, M.A., 2005. Sunflower oil. In: Shahidi, F. (ed.) Bailey's Industrial Oil \& Fat Products. Volume 2, Edible Oil \& Fat Products. Edible oil. $6^{\text {th }}$ ed.

Gunstone, F.D., 2005. Vegetable Oils. In: Shahidi, F. (ed.) Bailey's Industrial Oil \& Fat Products. Volume 1. Edible Oil \& Fat Products. Chemistry, Properties \& Health Effects. ${ }^{\text {th }}$ Ed.

Hartman, L., Antoniassi, R., Freitas, S.P., 1999. Characterization of Five Sunflower Varieties Cultivated in Brazil. Boletim CEPPA 17(2): 145-152.

Hartman, L., Lago, R.C., 1973. Rapid determination of fatty acid methyl esthers from lipids. Laboratory Practice, London, 22(7): 475-476, 494.

Pedrosa, M.M., Muzquiz, M., Garcia-Vallejo, C., Burbano, C., Cuadrado, C., Ayet, G., Robredo, L.M., 2000. Determination of caffeic and chlorogenic acids and their derivatives in different sunflower seeds. Journal of the Science of Food and Agriculture 80(4): 459-464.

Porto, W.S., Carvalho, C.G.P., Pinto, R.J.B., Oliveira, M.F.O., Oliveira, A.C.B., 2008. Evaluation of sunflowers cultivars for central Brazil. Sci. Agric. 65(2): 139-144.

Przybylski, R., Mag, T., Eskin, N.A.M., McDonald, B.E., 2005. Canola Oil. In: Shahidi, F. (ed.), Bailey's Industrial Oil \& Fat Products. Volume 2, Edible Oil \& Fat Products. Edible oil. $6^{\text {th }} \mathrm{Ed}$.

Sen, M., Bhattacharyya, D.K., 2000. Nutritional quality of sunflower seed protein fraction extracted with isopropanol. Plant Foods for Human Nutrition 55(3): 265-278.

Silva, C.A., Pinheiro, J.W., Fonseca, N.A.N., Cabrera, L., Novo, V.C.C., Silva, M.A.A., Canteri, R.C., Hoshi, E.H., 2002. Sunflower meal to swine on growing and finishing phase: digestibility, performance and carcass quality. Revista Bras. Zootec. 31(2): 982-990.

Singh, N., Singh, R., Kaur, K., Singh, H., 1999. Studies of the physico-chemical properties and polyphenoloxidase activity in seeds from hybrid sunflower (Helianthus annuus) varieties grown in India. Food-Chemistry 66(2): 241-247.

Stringhini, J.H., Café, M.B., Fernandes, C.M., Andrade, M.L., Rocha, P.T., Leandro, N.S.M., 2000. Evaluation of the nutritional value of sunflower meal for poultry. Ciéncia Animal Brasileira 1(2): 123-126.

Sunflower. Embrapa Soybean. [on-line]. Available at http://www.cnpso.embrapa.br/index.php?op page $=54 \& \operatorname{cod}$ pai $=38>$ Accessed 15 mar. 2007.

USDA. United States Department of Agriculture - Foreign Agricultural Service. Oilseeds: World Markets and Trade. [on line]. Available at: < http://www.fas.usda.gov/htp/> [Accessed 15 mar. 2007].

Van Soest, P.J., 1967. Development of a comprehensive system of feed analysis and its application to forages. J. Anim. Sci. 26(1): 119-128. 


\title{
COMPOSICIÓN QUÚMICA DE LAS VARIEDADES DE GIRASOL BRASILEÑAS
}

\author{
RESUMEN
}

Girasol es la cuarta fuente del aceite comestible más importante del mundo, después de aceite de palma, soya y colza/canola. El cultivo de girasol se ha consolidado en Brasil gracias a los empeños continuos en la esfera de estudios genéticos y agronómicos, realizados en las dependencias de investigación brasileñas. Aunque girasol se adaptaba fácilmente a las condiciones en muchas regiones de Brasil, fueron necesarios los adelantos genéticos y agronómicos para que se lograra una producción económicamente justificada. Se han creado las variedades de girasol con el contenido de aceite interesante y alta calidad de proteínas. Dentro de este trabajo, la Compañía Embrapa Soybean creyó dos variedades nuevas, Embrapa 122 V2000 y Embrapa $F_{2}$ BRS 191. El objetivo de este trabajo ha sido evaluar el contenido químico de la semilla, tortilla desengrasada y aceite en dichas variedades. El contenido de aceite oscilaba entre 44 y $52 \%$ en $\mathrm{F}_{2}$ BRS y de $36 \mathrm{~s} 47 \%$ en $\mathrm{E} 122$. El ácido linólico (62-69\%) y oleíco (20-25\%) fueron principales ácidos grasos en ambas variedades. El contenido de proteínas en la tortilla desengrasada oscilaba entre 28 y $32 \%$. Fueron notadas pequeñas diferencias en el perfil de aminoácidos y el contenido de esterol y ácido clorogénico.

\section{COMPOSITION CHIMIQUE DE SORTES DE TOURNESOL BRÉSILIENNES}

RÉSUMÉ

Le tournesol est la quatrième source d'huile comestible au monde, après l'huile de palme, l'huile de soja et l'huile de colza/navette. La culture du tournesol s'est implantée au Brésil grâce aux efforts constants des instituts de recherche du pays dans le domaine des recherches génétiques et agronomiques. Bien que le tournesol se soit facilement adapté aux conditions de nombreuses régions du Brésil, des progrés dans la génétique et l'agronomie ont été nécessaires à l'obtention d'une production justifiée économiquement. Des sortes de tournesol ayant une teneur en huile intéressante et une grande qualité de protéines ont été créées. Dans le cadre de ce travail, la firme Embrapa Soybean a créé deux nouvelles sortes, Embrapa 122 V2000 et Embrapa $F_{2}$ BRS 191. Le but de ce travail était d'évaluer la composition chimique de la graine, du tourteau dégraissé et de l'huile. La teneur en huile allait de 44 à $52 \%$ pour le $\mathrm{F}_{2}$ BRS et de 36 à $47 \%$ pour le E 122 . L'acide linoléique (62-69\%) et l'acide oléique (20-25\%) étaient les acides gras les plus importants pour les deux sortes. La teneur en protéines dans le tourteau dégraissé allait de 28 à $32 \%$. On a remarqué de petites différences dans le profil de l'acide aminé et la teneur en stérols et en acide chlorogénique. 
